\title{
Effects of nitrogen dosage and urea source on morphological composition and forage accumulation in massai grass ${ }^{1}$
}

\section{Composição morfológica e acúmulo de forragem do capim Massai sob doses de nitrogênio e fontes de ureia}

\author{
Aline Barros da Silva ${ }^{2 *}$; Carlos Augusto Brandão Carvalho ${ }^{3}$; Camila de Almeida \\ Pires $^{4}$; João Carlos de Carvalho Almeida ${ }^{2}$; Delci de Deus Nepomuceno ${ }^{5}$
}

\begin{abstract}
The effects of nitrogen (N) dose and urea source on forage mass (FM), percentage of dry matter of leaf blades (LBDMP), stem (SDMP), and dead material (DMDMP), and the forage accumulation rate (FAR) of Panicum maximum 'Massai' (massai grass) were evaluated. We set up an experiment with a completely randomized block design in a factorial arrangement $(3 \times 2)+1$, consisting of three doses $(100,200$, and $400 \mathrm{~kg} \mathrm{ha}^{-1}$ year-1 $^{-1}$ ), two urea sources (common and coated with Policote ${ }^{\circledR}$ ), and a control treatment, in five consecutive climatic seasons, including the summers of 2011/2012 (summer I), autumn, winter, and spring of 2012, and the summers of 2012/2013 (summer II). We found an interaction effect between N dose, urea source, and season $(\mathrm{p}<0.05)$. LBDMP linearly increased during dry periods (autumn and winter) and SDMP in autumn and DMDMP in winter linearly decreased when coated urea were used. FAR showed a linear increase with the use of both urea sources, except for common urea in autumn, and the increases in the winter were owing to a greater contribution of leaf blades to FM. The use of coated urea for $\mathrm{N}$ fertilization linearly increases FAR in all seasons of the year and improves the morphological composition of the forage of massai grass, mainly in dry seasons.
\end{abstract}

Key words: Forage accumulation rate. Leaf blade dry matter percentage. Nitrogen fertilization. Panicum maximum.

\section{Resumo}

Avaliou-se a eficiência de doses de nitrogênio $(\mathrm{N})$ e fontes de ureia sobre as variáveis massa de forragem (MF), porcentagens de massa seca de lâminas foliares (PMSLF), colmos (PMSC) e de material morto (PMSMM), além da taxa de acúmulo de forragem (TAF) do Panicum maximum cv. Massai (capim Massai). Para tanto, delineou-se um experimento em blocos completos casualizados, em arranjo fatorial $(3 \times 2)+1$; constando de três doses de N $(100,200$ e $400 \mathrm{~kg}$ ha-1 ano-1), duas fontes ureia (comum e revestida com Policote ${ }^{\circledR}$ ) e um tratamento controle, em cinco estações climáticas consecutivas, verão de 2011/2012 (verão I), outono, inverno e primavera de 2012, e verão de 2012/2013 (verão II). As variáveis analisadas apresentaram efeito de interação entre dose de $\mathrm{N}$, fonte de ureia e estações do ano $(\mathrm{p}<0,05)$. Houve aumento linear da PMSLF durante o período seco (outono e inverno) e redução linear

\footnotetext{
1 Parte da Dissertação de Mestrado do terceiro autor.

2 Discente, Curso de Doutorado do Programa de Pós-Graduação em Zootecnia, Universidade Federal Rural do Rio de Janeiro, UFRRJ, Seropédica, RJ, Brasil. E-mail: aline_barros2006@hotmail.com

3 Profs. Drs., DNAP, UFRRJ, Seropédica, RJ, Brasil. E-mail: carloscarvalho_ufrrj@yahoo.com.br; joaocarlosbq@gmail.com

4 M.e, em Ciências PPGZ-UFRRJ, Seropédica, RJ, Brasil. E-mail: apires.camila@gmail.com

5 † Dr., DNAP, UFRRJ, Seropédica, RJ, Brasil.

* Author for correspondence
} 
da PMSC no outono e da PMSMM no inverno para o uso da ureia revestida. As TAF apresentaram aumento linear com uso de ambas às fontes de ureia, exceto para ureia comum no outono, e aquelas obtidas durante o inverno ocorreram em função das maiores participações de lâminas foliares nas MF. O aumento da adubação nitrogenada com ureia revestida aumenta de forma linear positiva a taxa de acúmulo de forragem em todas as estações do ano e melhora a composição morfológica da forragem do capim Massai, principalmente em estações com déficit hídrico.

Palavras-chave: Adubação nitrogenada. Panicum maximum. Porcentagem de massa seca de lâminas foliares. Taxa de acúmulo de forragem.

\section{Introduction}

Massai grass (Panicum maximum 'Massai'), a spontaneous hybrid between $P$. maximum and $P$. infestum (LEMPP et al., 2001), produces approximately $15.6 \mathrm{t} \mathrm{ha}^{-1}$ of dry leaf mass (similar to the 14.3 tha $^{-1}$ of the 'Colonião'). This cultivar has a greater capacity for leaf production in relation to the stem (30\%) and for regrowth (83\%), and a lower seasonality of production (53\%) than Colonião, in spite of its smaller size $(0.60 \mathrm{~m}$ versus $1.50 \mathrm{~m}$ of Colonião), it presents about $80 \%$ of leaves in the forage mass, similar to the cultivars Tanzania and Mombaça, and crude protein content in the leaves $(12.5 \%)$ and stems $(8.5 \%)$ are similar to those in Tanzania (JANK et al., 2010).

Morphogenetic and structural characteristics of forage plants (including their morphological composition) are influenced by abiotic factors, such as temperature, management, frequency and intensity of defoliation, and fertilization (MARTUSCELLO et al., 2015). However, studies to elucidate the effects of these factors on morphological composition and forage accumulation in massai grass are scarce.

Regarding nitrogen fertilization, urea is the most commonly used source globally because it contains approximately $45 \%$ nitrogen in the amide form $\left[\mathrm{CO}\left(\mathrm{NH}_{2}\right)_{2}\right]$, in addition to the fact that it is less costly than other sources of N (PEREIRA et al., 2009; MARTINS et al., 2014). Other sources result in higher $\mathrm{N}$ losses related to volatilization of ammonia $\left(\mathrm{NH}_{3}^{+}\right)$, denitrification, soil erosion (CIVARDI et al., 2011), and immobilization by microbial biomass (ROCHA et al., 2014). The efficiency of this $\mathrm{N}$ source $\mathrm{N}$ in the end benefits the profitability of livestock enterprises (SANTINI et al., 2015).

The use of coated fertilizer has appeared as an alternative solution to improve $\mathrm{N}$ efficiency owing to the reduction of losses caused by leaching, immobilization, and volatilization. Additional benefits include regular and continuous nutrient supply to plants, lower frequency of soil applications, elimination of damage to roots due to high salt concentration, greater practicality in handling, as well as contribution to the reduction of environmental pollution by $\mathrm{NO}_{3}^{-}$(MORGAN et al., 2009). Considering the potential of coated fertilizers and the fact that the efficiency of $\mathrm{N}$ fertilization contributes to the increase of pasture productivity, Sanchês et al. (2013) suggested the search for alternative $\mathrm{N}$ sources and different pasture fertilization schemes.

The use of nitrogen fertilizers covered by organic substances, polymers, or synthetic resins in maize cultivation has been reported (VALDERRAMA et al., 2014). However, reports on coated N-sources are mostly restricted to ruminant feeds for livestock (AZEVEDO et al., 2008), while studies on the use of coated urea for pasture fertilization are scarce. Therefore, it is necessary to determine $\mathrm{N}$ sources, doses, and frequencies that increase $\mathrm{N}$ efficiency and forage production.

Accordingly, this study aimed to evaluate the effect of $\mathrm{N}$ doses and urea sources on forage accumulation and morphological composition of massai grass during the summer seasons of 2011/2012 (summer I), autumn, winter, and spring of 2012, and summers of 2012/2013 (summer II). 


\section{Material and Methods}

The experiment was conducted at the Experimental Field of the Department of Animal Nutrition and Pasture of the Instituto de Zootecnia of the Universidade Federal Rural do Rio de Janeiro, Seropédica city, Brazil, at $22^{\circ} 45^{\prime}$ southern latitude and $43^{\circ} 41^{\prime}$ western longitude and $33 \mathrm{~m}$ a.s.l. The trial period comprised one year and five months, starting on December 20, 2011 and ending on May
3, 2013. The climate of the region is Aw (Köppen), with a dry season that runs from April to September and a hot and rainy season from October to March. Climatic data for the determination of the water balance (THORNTHWAITE; MATHER, 1955) in the experimental period were obtained from the website of the Instituto Nacional de Meteorologia, based on data from the Estação Experimental de Seropédica, and are shown in Figures 1 and 2.

Figure 1. Precipitation (mm), temperatures maximum $-{ }^{\circ} \mathrm{C}(---)$ and minimum $-{ }^{\circ} \mathrm{C}(-)$ December of de 2011 of April of 2013 of the experimental area.

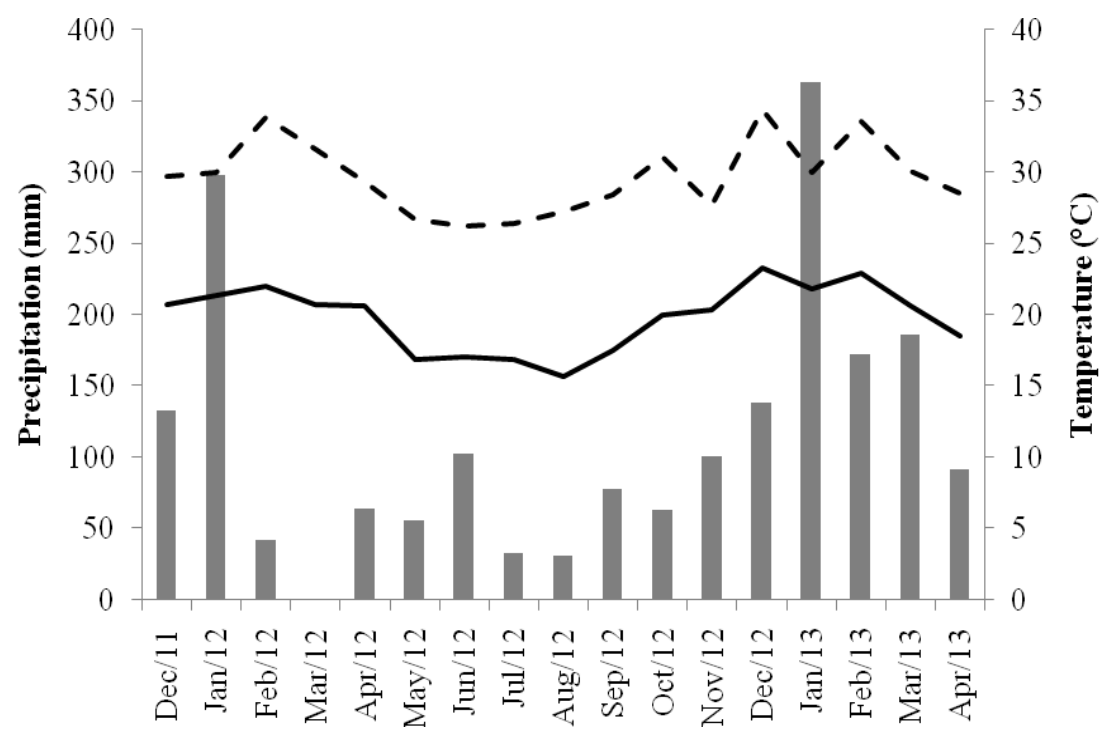

Figure 2. Extract of the monthly water balance of December 2011 to April 2013, according to Thornthwaite \& Mather (1955) - Source: Site Data Bank of the National Institute of Meteorology (INMET).

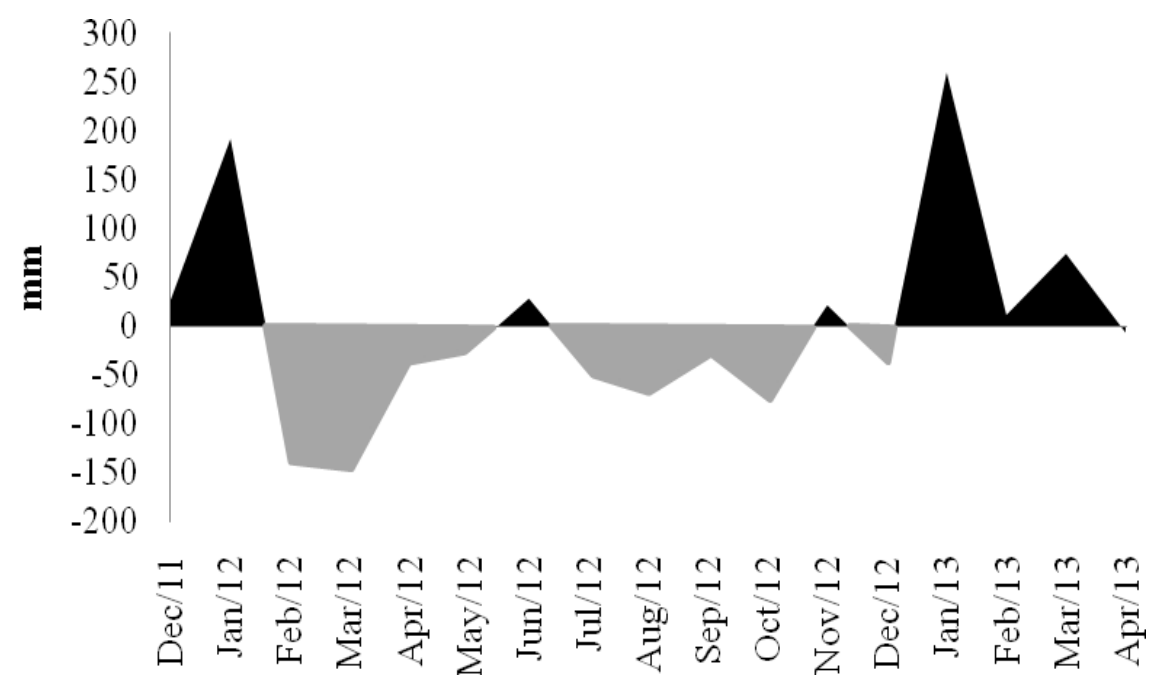


Soil sampling of the $0-20 \mathrm{~cm}$ layer was carried out prior to seeding of the Massai grass, on June 22, 2010, and chemical analysis revealed the following characteristics: $\mathrm{pH}$ in $\mathrm{H}_{2} \mathrm{O}=5.78$; $\mathrm{P}\left(\mathrm{Mehlich}^{-1}\right)=$ $18.50 \mathrm{mg} \mathrm{dm}^{-3} ; \mathrm{K}\left(\mathrm{Mehlich}^{-1}\right)=0.24 \mathrm{Cmol}_{\mathrm{c}} \mathrm{dm}^{-3}$; $\mathrm{Ca}^{2+}\left(\mathrm{KCl} 1 \mathrm{~mol} \mathrm{~L}^{-1}\right)=1.48 \mathrm{Cmol}_{\mathrm{c}} \mathrm{dm}^{-3} ; \mathrm{Mg}^{2+}(\mathrm{KCl}$ $\left.1 \mathrm{~mol} \mathrm{~L}^{-1}\right)=0.60 \mathrm{Cmol}_{\mathrm{c}} \mathrm{dm}^{-3} ; \mathrm{Al}^{3+}\left(\mathrm{KCl} 1 \mathrm{~mol} \mathrm{~L}^{-1}\right)$ $=0.20 \mathrm{Cmol}_{\mathrm{c}} \mathrm{dm}^{-3} ; \mathrm{H}+\mathrm{Al}=1.53 \mathrm{Cmol}_{\mathrm{c}} \mathrm{dm}^{-3}$; cation exchange capacity $=3.86 \mathrm{Cmol} \mathrm{dm}^{-3}$; base saturation $=60.50 \%$; organic material $=2.50 \mathrm{~g} \mathrm{dm}^{-3}$.

In total, $4.8 \mathrm{t} \mathrm{ha}^{-1}$ of dolomitic limestone (PRNT $76 \%$ ) was applied to the surface on December 22, 2010 , prior to plowing and harvesting, and simple superphosphate $\left(80 \mathrm{~kg} \mathrm{ha}^{-1}\right.$ of $\left.\mathrm{P}_{2} \mathrm{O}_{5}\right)$ was applied in the sowing furrow December 23, 2010, according to recommendations by Portz et al. (2013). Massai grass was seeded ( $2 \mathrm{~kg}$ of viable pure seeds $\mathrm{ha}^{-1}$ ) at $2.0 \mathrm{~cm}$ depth in four 4-m-long rows spaced 0.5 $\mathrm{m}$ apart (parcels of $8 \mathrm{~m}^{2}$ each), on May 5, 2011. Fertilization with urea and potassium chloride as sources of $\mathrm{N}$ and $\mathrm{K}_{2} \mathrm{O}$, respectively, was applied at $12 \mathrm{~kg} \mathrm{ha}^{-1}$ of $\mathrm{N}$ and $\mathrm{K}_{2} \mathrm{O}$ on May 25 2011, and 28 and $12 \mathrm{~kg} \mathrm{ha}^{-1}$ of $\mathrm{N}$ and $\mathrm{K}_{2} \mathrm{O}$, respectively, on July 16, 2011. On August 9, 2011 plants were cut at 10 $\mathrm{cm}$ above the soil for uniformization of the plants in all plots, and 10 days after the cutting, coated urea surface fertilizations (Policote ${ }^{\circledR}$ ) were applied according to the technical recommendations of the manufacturer.

The experiment was designed in a randomized complete block, with four replications, under a factorial arrangement $(3 \times 2)+1$ representing three doses of $\mathrm{N}\left(100,200\right.$, and $400 \mathrm{~kg} \mathrm{ha}^{-1}$ year $\left.^{-1}\right)$, two sources of $\mathrm{N}$ (urea and Policote ${ }^{\circledR}$ coated urea) and a control treatment (without $\mathrm{N}$ fertilization). The analysis involved time-repeated measurements during the summer seasons of 2011/2012 (summer I), autumn, winter and spring 2012, and the summers of 2012/2013 (summer II). N doses were fractionated in five equal applications throughout the year, with one application for each treatment in summer I (January 17, 2012 to January 24, 2012); one for treatments of $100 \mathrm{~kg}$ and $200 \mathrm{~kg} \mathrm{ha}^{-1}$ year $^{-1}$ of coated urea and $200 \mathrm{~kg} \mathrm{ha}^{-1}$ year $^{-1}$ of common urea, and two applications for the other treatments in autumn (April 13, 2012 to June 12, 2012); one application in winter (July 12, 2012 to November 01, 2012) and in spring (November 06, 2012 to December 28, 2012) for all treatments; and one in summer II (February 11, 2013 and February 28, 2013) for treatments of $200 \mathrm{~kg} \mathrm{ha}^{-1}$ year ${ }^{-1}$ of common urea and 100 and $200 \mathrm{~kg} \mathrm{ha}^{-1}$ year $^{-1}$ protected urea. Fertilizers were applied 10 days after the cutting of the forage plants. Potassium fertilization $(400 \mathrm{~kg}$ $\mathrm{ha}^{-1} \mathrm{yr}^{-1} \mathrm{~K}_{2} \mathrm{O}$ ) was applied using potassium chloride together with nitrogen fertilization, in five equal plots during the experimental period, for the control treatment. The experimental units were plots of 8 $\mathrm{m}^{2}$ each $(4 \times 2 \mathrm{~m})$.

Weekly, the percentage of photosynthetically active radiation (IL) was evaluated by means of 12 simultaneous readings above and below the forage canopy, in each plot, using an AccuPAR Linear PAR/LAI ceptometer (Model PAR-80) canopy analyzer. When the mean IL of each treatment reached $95 \%$, the plants were manually at $10 \mathrm{~cm}$ above the soil. The heights of the forage canopies were measured at the same time the IL readings were taken, accounting for 20 measurements per experimental unit, based on the curvatures of the last expanded leaves, as described by Carnevalli et al. (2006), using a ruler graduated in millimeters.

Forage mass (FM) was estimated by cutting in an area of $3 \mathrm{~m}^{2}$ of each experimental unit. The forage was cut manually at $10 \mathrm{~cm}$ above the soil (10 $\mathrm{cm}$ residue height). The collected samples were conditioned in identified, heavy, and subsampled plastic bags (500 g). Each sub-sample was fractionated in dead material, pseudo stems (stem + leaf sheath), and leaf blades, and all fractions were dried in a forced-air ventilation oven at $55^{\circ} \mathrm{C}$ for 72 $\mathrm{h}$ to obtain the respective dry matter content. The dry masses of leaf, stem, and dead material fractions were expressed as a percentage (\%) as follows: 
percentages of dry masses of leaf blades (LBDMP), stem (SDMP), and dead material (DMDMP), and their morphological compositions calculated on the basis of the representation of the dry mass of each fraction in the FM of the samples. Forage accumulation rates (FARs) were estimated on the basis of the sum of the FM of each treatment during the experimental period.

Data were subjected to analysis of variance (ANOVA) using the procedure PROC MIXED of the statistical package SAS (Statistical Analysis System), version 9.2 for Windows, specifically for cases of measures repeated in time and in which time is a factor to be studied as cause of variation. The choice of variance and covariance matrix was made using the Akaike information criterion (AIC) and ANOVA based on the following causes of variation: block, urea source, $\mathrm{N}$ dose, season, and interactions between them. The effects of urea source, $\mathrm{N}$ dose, season, and their interactions were considered fixed. Block and the interactions were considered random. To evaluate the effects of quantitative factors $(\mathrm{N}$ dose), the data were evaluated by regression analysis using PROC REG in SAS. For qualitative effects (urea source and season), means for the treatments were estimated by LSMEANS and compared with PDIFF. A probability of $5 \%$ was used for all the tests.

\section{Results and Discussion}

We identified an interaction effect $(\mathrm{p}<0.0001)$ between urea source, nitrogen dose, and season on FM (Table 1). FM linearly increased with dose increase for both sources of urea in summer I, with a the largest effect observed for $400 \mathrm{~kg} \mathrm{ha}^{-1}$ year $^{-1}$ of $\mathrm{N}$ dose of common urea on FM in this season, as well as in spring $\left(4,554\right.$ and $8,586 \mathrm{~kg} \mathrm{ha}^{-1}$, respectively).

For the $\mathrm{N}$ dose of $100 \mathrm{~kg} \mathrm{ha}^{-1}$ year $^{-1}$, the use of coated urea resulted in higher FM $\left(4,778 \mathrm{~kg} \mathrm{ha}^{-1}\right.$ of $\mathrm{DM}$ ) in the winter (Figure 1). This suggests lower loss of urea to the environment in winter, as the water deficit is attenuated in this season and the urea is less susceptible to hydrolysis, which is accelerated by increasing soil water content and elevated temperature, which typically occur during spring and summer (ROJAS et al., 2012). However, Primavesi et al. (2006) reported that $\mathrm{N}$ losses due to leaching in pasture environments are not problematic, while potential $\mathrm{N}$ losses due to volatilization in tropical regions or in summer crops are higher than those in regions of temperate climate or than in autumnwinter fertilizations (CANTARELLA, 2007).

There were interaction effects $(p<0.0001)$ between urea source, $\mathrm{N}$ dose, and season on LBDMP, SDMP, and DMDMP (Table 2). The use of coated urea resulted in a linear increase in LBDMP and a linear reduction in SDMP in the fall. This effect was considered to be beneficial for obtaining forage with greater participation of leaf blade dry mass and smaller stem and dead material dry masses, mainly in dry periods, culminating in a possible higher nutritive value. Similar behavior was observed in winter, with a positive linear effect on LBDMP for both sources of urea and a decrease in DMDMP only for coated urea. In spring, there was no effect of $\mathrm{N}$ dose on LBDMP, and there was a linear increase in SDMP for both sources of urea, whereas DMDMP increased linearly only for common urea, which is not beneficial to the fodder produced in this same season. This effect seems to be directly related to the water deficit observed in the spring, especially in October (Figure 2). At the physiological level, this effect may be related to the $\mathrm{N}$ fertilization response, as $\mathrm{N}$ is the main constituent of proteins that actively participate in the synthesis of the organic compounds that determine structural plant characteristics such as leaf size, tiller and leaf density per tiller, as well as morphogenic characteristics, such as leaf appearance and leaf elongation rates (COSTA et al., 2006). 
Table 1. Forage mass of massai grass, as a function of urea sources; nitrogen doses; and the Summer of 2011/2012 (summer I), autumn, winter and spring of 2012, and summer of 2012/2013 (Summer II) seasons.

\begin{tabular}{|c|c|c|c|c|c|c|c|c|}
\hline \multirow{2}{*}{ Seasons } & \multicolumn{5}{|c|}{$\mathrm{N}\left(\mathrm{kg} \mathrm{ha}^{-1} \mathrm{yr}^{-1}\right)$} & \multirow{2}{*}{ SEM } & \multirow{2}{*}{ Equations } & \multirow{2}{*}{$\mathrm{R}^{2}$} \\
\hline & 0 & Ureia & 100 & 200 & 400 & & & \\
\hline \multicolumn{9}{|c|}{ Forage mass $\left(\mathrm{kg} \mathrm{ha}^{-1}\right)$} \\
\hline \multirow{2}{*}{$\begin{array}{c}\text { Summer } \\
\text { I }\end{array}$} & \multirow{2}{*}{$2916^{\mathrm{C}}$} & Commonn & $3922^{\mathrm{B}}$ & $3782^{\mathrm{B}}$ & $4554^{\mathrm{A}}$ & \multirow{2}{*}{203} & $\hat{\mathrm{Y}}=3164+3.5971 \mathrm{x} * *$ & 0.83 \\
\hline & & Coated & $3678^{\mathrm{B}}$ & $3816^{\mathrm{B}}$ & $3881^{\mathrm{B}}$ & & $\hat{Y}=3207.8+2.0854 x^{*}$ & 0.64 \\
\hline \multirow{2}{*}{ Autumn } & \multirow{2}{*}{$4046^{\mathrm{D}}$} & Common & $5569^{\mathrm{AB}}$ & $5750^{\mathrm{AB}}$ & $5149^{\mathrm{BC}}$ & \multirow{2}{*}{360} & $\hat{Y}=4129.6+15.407 x-0.0323 x^{2 * *}$ & 0.95 \\
\hline & & Coated & $6237^{\mathrm{A}}$ & $6385^{\mathrm{A}}$ & $4281^{\mathrm{C}}$ & & $\hat{\mathrm{Y}}=4148.4+24.151 \mathrm{x}-0.0598 \mathrm{x}^{2 * *}$ & 0.97 \\
\hline \multirow{2}{*}{ Winter } & \multirow{2}{*}{$3342^{\mathrm{B}}$} & Common & $2863^{\mathrm{B}}$ & $2901^{\mathrm{B}}$ & $2626^{\mathrm{B}}$ & \multirow{2}{*}{355} & $\hat{Y}=2933$ & - \\
\hline & & Coated & $4778^{\mathrm{A}}$ & $2570^{\mathrm{B}}$ & $2375^{\mathrm{B}}$ & & $\hat{\mathrm{Y}}=3755.3+0.2077 \mathrm{x}-0.01 \mathrm{x}^{2 *}$ & 0.41 \\
\hline \multirow{2}{*}{ Spring } & \multirow{2}{*}{$5363^{\mathrm{CD}}$} & Common & $6284^{\mathrm{BC}}$ & $7136^{\mathrm{B}}$ & $8586^{\mathrm{A}}$ & \multirow{2}{*}{341} & $\hat{\mathrm{Y}}=5441.1+8.0073 \mathrm{x}^{* *}$ & 0.99 \\
\hline & & Coated & $5039^{\mathrm{D}}$ & $5590^{\mathrm{CD}}$ & $4934^{\mathrm{D}}$ & & $\hat{\mathrm{Y}}=5231$ & - \\
\hline \multirow{2}{*}{$\begin{array}{l}\text { Summer } \\
\text { II }\end{array}$} & \multirow{2}{*}{$4992^{\mathrm{C}}$} & Common & $7717^{\mathrm{A}}$ & $8037^{\mathrm{A}}$ & $7716^{\mathrm{A}}$ & \multirow{2}{*}{379} & $\hat{Y}=6146.3+5.5386 x^{*}$ & 0.44 \\
\hline & & Coated & $7271^{\mathrm{AB}}$ & $8287^{\mathrm{A}}$ & $6266^{\mathrm{B}}$ & & $\hat{\mathrm{Y}}=4964.4+31.25 \mathrm{x}-0.0745 \mathrm{x}^{2 * *}$ & 0.99 \\
\hline
\end{tabular}

Mean values within the same station followed by the same capital letter do not differ by PDIFF $(p>0.05)$. $R^{2}=$ coefficient of determination of the regression equation. X: $\mathrm{kg} \mathrm{ha}^{-1} \mathrm{~kg} \mathrm{ha}^{-1}$ year $^{-1}$ of N. SEM: Standard error of the mean. $*(\mathrm{p}<0.05)$ and $* *(\mathrm{p}<$ $0.01)$.

In summer II, the data obtained for LBDMP did not fit any regression model for both sources of urea, but we observed a large contribution of this component to FM for common and coated urea (averages of 57.0 and $58.8 \%$, respectively), as contributions of SDMP and DMDMP that presented linear and quadratic effects, respectively, for both sources of urea, were lower.

There was an interaction effect $(p<0.0001)$ between urea source, $\mathrm{N}$ dose, and season on FAR (Table 3). Fertilization at $400 \mathrm{~kg} \mathrm{ha}^{-1}$ year $^{-1}$ of $\mathrm{N}$ of coated urea promoted higher FAR in summer I, autumn, and spring $\left(210,104\right.$, and $87 \mathrm{~kg} \mathrm{ha}^{-1}$ day $^{-1}$, respectively), reflecting the potential of massai grass in the face of the diversity of climatic conditions observed during these periods. This fact was confirmed by the positive linear behavior of FAR for both sources of urea in all seasons, except for the use of common urea in autumn (no effect). Costa et al. (2009) reported that the positive effect of $\mathrm{N}$ rate on forage production may be related to the fact that $\mathrm{N}$ supply by the soil does not normally meet the nutritional requirements of grasses, and the effect of $\mathrm{N}$ can be attributed to its substantial influence on the physiological processes of the plant (PORTO et al., 2014). 
Table 2. Leaf blade, stem and dead material dry masses percentages of massai grass as a function of urea sources; nitrogen doses; and the summer of 2011/2012 (summer I), autumn, winter and spring of 2012, and summer of 2012/2013 (summer II) seasons.

\begin{tabular}{|c|c|c|c|c|c|c|c|c|}
\hline \multirow{2}{*}{ Seasons } & \multicolumn{5}{|c|}{$\mathrm{N}\left(\mathrm{kg} \mathrm{ha}^{-1} \mathrm{yr}^{-1}\right)$} & \multirow{2}{*}{ SEM } & \multirow{2}{*}{ Equations } & \multirow{2}{*}{$\mathrm{R}^{2}$} \\
\hline & 0 & Ureia & 100 & 200 & 400 & & & \\
\hline \multicolumn{9}{|c|}{ Leaf blade dry mass percentage (\% FM) } \\
\hline \multirow{2}{*}{$\begin{array}{l}\text { Summer } \\
\text { I }\end{array}$} & \multirow{2}{*}{$66.7^{\mathrm{B}}$} & Common & $78.1^{\mathrm{A}}$ & $75.7^{\mathrm{A}}$ & $75.3^{\mathrm{A}}$ & \multirow{2}{*}{1.7} & $\hat{Y}=73.9$ & - \\
\hline & & Coated & $77.2^{\mathrm{A}}$ & $77.5^{\mathrm{A}}$ & $77.9^{\mathrm{A}}$ & & $\hat{\mathrm{Y}}=74.8$ & - \\
\hline \multirow{2}{*}{ Autumn } & \multirow{2}{*}{$55.2^{\mathrm{BC}}$} & Common & $67.5^{\mathrm{A}}$ & $43.2^{\mathrm{D}}$ & $65.2^{\mathrm{A}}$ & \multirow{2}{*}{2.9} & $\hat{Y}=57.7$ & - \\
\hline & & Coated & $52.2^{\mathrm{BC}}$ & $44.4^{\mathrm{CD}}$ & $72.5^{\mathrm{A}}$ & & $\hat{Y}=48.435+0.044 x^{*}$ & 0.40 \\
\hline \multirow{2}{*}{ Winter } & \multirow{2}{*}{$58.8^{\mathrm{B}}$} & Common & $88.6^{\mathrm{A}}$ & $89.8^{\mathrm{A}}$ & $89.6^{\mathrm{A}}$ & \multirow{2}{*}{3.0} & $\hat{Y}=70.765+0.626 x^{*}$ & 0.49 \\
\hline & & Coated & $83.1^{\mathrm{A}}$ & $65.6^{\mathrm{B}}$ & $89.1^{\mathrm{A}}$ & & $\hat{\mathrm{Y}}=63.83+0.0589 \mathrm{x}^{*}$ & 0.50 \\
\hline \multirow{2}{*}{ Spring } & \multirow{2}{*}{$55.5^{\mathrm{E}}$} & Common & $60.9^{\mathrm{DE}}$ & $61.6^{\mathrm{CDE}}$ & $58.2^{\mathrm{E}}$ & \multirow{2}{*}{2.1} & $\hat{\mathrm{Y}}=59.0$ & - \\
\hline & & Coated & $67.0^{\mathrm{BCD}}$ & $71.3^{\mathrm{A}}$ & $68.2^{\mathrm{BC}}$ & & $\hat{Y}=65.5$ & - \\
\hline \multirow{2}{*}{$\begin{array}{l}\text { Summer } \\
\text { II }\end{array}$} & \multirow{2}{*}{$51.0^{\mathrm{C}}$} & Common & $60.1^{\mathrm{AB}}$ & $61.0^{\mathrm{AB}}$ & $56.1^{\mathrm{BC}}$ & \multirow{2}{*}{3.0} & $\hat{Y}=57.0$ & - \\
\hline & & Coated & $66.0^{\mathrm{A}}$ & $56.2^{\mathrm{BC}}$ & $62.0^{\mathrm{AB}}$ & & $\hat{\mathrm{Y}}=58.8$ & - \\
\hline \multicolumn{9}{|c|}{ Stems dry mass percentage $(\% \mathrm{FM})$} \\
\hline \multirow{2}{*}{$\begin{array}{c}\text { Summer } \\
\text { I }\end{array}$} & \multirow{2}{*}{$16.7^{\mathrm{AB}}$} & Common & $17.2^{\mathrm{AB}}$ & $17.9^{\mathrm{AB}}$ & $19.7^{\mathrm{A}}$ & \multirow{2}{*}{1.4} & $\hat{\mathrm{Y}}=17.8$ & - \\
\hline & & Coated & $17.7^{\mathrm{AB}}$ & $16.9^{\mathrm{AB}}$ & $15.6^{\mathrm{B}}$ & & $\hat{Y}=16.7$ & - \\
\hline \multirow{2}{*}{ Autumn } & \multirow{2}{*}{$42.0^{\mathrm{AB}}$} & Common & $23.9^{\mathrm{C}}$ & $45.5^{\mathrm{AB}}$ & $30.0^{\mathrm{C}}$ & & $\hat{\mathrm{Y}}=35.3$ & - \\
\hline & & Coated & $38.9^{\mathrm{B}}$ & $47.2^{\mathrm{A}}$ & $24.7^{\mathrm{C}}$ & 2.7 & $\hat{Y}=45.445-0.0408 x^{*}$ & 0.51 \\
\hline & & Common & $9.5^{\mathrm{A}}$ & $4.5^{\mathrm{A}}$ & $9.5^{\mathrm{A}}$ & & $\hat{\mathrm{Y}}=9.1$ & - \\
\hline Winter & $12.8^{\mathrm{A}}$ & Coated & $11.8^{\mathrm{A}}$ & $5.2^{\mathrm{A}}$ & $8.7^{\mathrm{A}}$ & 3.4 & $\hat{\mathrm{Y}}=9.6$ & - \\
\hline & & Common & $24.3^{\mathrm{A}}$ & $21.7^{\mathrm{AB}}$ & $24.9^{\mathrm{A}}$ & & $\hat{Y}=18.675+0.0175 x^{*}$ & 0.53 \\
\hline Spring & $15.9^{\mathrm{B}}$ & Coated & $20.9^{\mathrm{AB}}$ & $20.8^{\mathrm{AB}}$ & $20.0^{\mathrm{AB}}$ & 2.2 & $\hat{\mathrm{Y}}=18.06+0.0077 \mathrm{x}^{*}$ & 0.30 \\
\hline Summer & & Common & $33.3^{\mathrm{AB}}$ & $34.0^{\mathrm{AB}}$ & $30.6^{\mathrm{B}}$ & & $\hat{\mathrm{Y}}=39.506-0.0251 \mathrm{x}^{*}$ & 0.80 \\
\hline II & $38.4^{\mathrm{A}}$ & Coated & $33.6^{\mathrm{AB}}$ & $35.7^{\mathrm{AB}}$ & $30.0^{\mathrm{B}}$ & 2.0 & $\hat{\mathrm{Y}}=40.235-0.0269 \mathrm{x}^{*}$ & 0.77 \\
\hline & & & Dead & material & ry mass 1 & centag & (FM) & \\
\hline Summer & & Common & $3.8^{\mathrm{D}}$ & $7.1^{\mathrm{A}}$ & $4.9^{\mathrm{BC}}$ & & $\hat{\mathrm{Y}}=5.7$ & - \\
\hline I & $7.1^{\mathrm{A}}$ & Coated & $4.5^{\mathrm{CD}}$ & $4.6^{\mathrm{CD}}$ & $5.7^{\mathrm{B}}$ & 0.4 & $\hat{\mathrm{Y}}=5.5$ & - \\
\hline & & Common & $7.4^{\mathrm{B}}$ & $11.2^{\mathrm{A}}$ & $3.8^{\mathrm{C}}$ & & $\hat{\mathrm{Y}}=6.2$ & - \\
\hline Autumn & $2.5^{c}$ & Coated & $7.7^{\mathrm{B}}$ & $8.2^{\mathrm{B}}$ & $2.7^{\mathrm{C}}$ & 0.5 & $\hat{Y}=5.3$ & - \\
\hline & & Common & $1.1^{\mathrm{D}}$ & $3.5^{\mathrm{BC}}$ & $4.3^{\mathrm{B}}$ & & $\hat{\mathrm{Y}}=5.3$ & - \\
\hline Winter & $12.2^{\mathrm{A}}$ & Coated & $3.6^{\mathrm{BC}}$ & $11.9^{\mathrm{A}}$ & $1.6^{\mathrm{CD}}$ & 0.8 & $\hat{Y}=18.835-0.0372 x^{*}$ & 0.38 \\
\hline & & Common & $14.7^{\mathrm{B}}$ & $15.7^{\mathrm{AB}}$ & $16.8^{\mathrm{A}}$ & & $\hat{\mathrm{Y}}=10.755+0.0182 \mathrm{x}^{* *}$ & 0.69 \\
\hline Spring & $8.5^{\mathrm{D}}$ & Coated & $12.0^{\mathrm{C}}$ & $7.7^{\mathrm{D}}$ & $11.7^{\mathrm{C}}$ & 0.8 & $\hat{\mathrm{Y}}=9.9$ & - \\
\hline Summer & $128 \mathrm{~A}$ & Common & $6.5^{\mathrm{CD}}$ & $8.1^{\mathrm{BC}}$ & $8.2^{\mathrm{B}}$ & & $\hat{\mathrm{Y}}=12.084-0.0454 \mathrm{x}+0.0001 \mathrm{x}^{2 *}$ & 0.70 \\
\hline II & $12.8^{\mathrm{A}}$ & Coated & $6.4^{\mathrm{D}}$ & $8.5^{\mathrm{B}}$ & $8.0^{\mathrm{BCD}}$ & 1.1 & $\hat{\mathrm{Y}}=11.991-0.0422 \mathrm{x}+0.0001 \mathrm{x}^{2 *}$ & 0.65 \\
\hline
\end{tabular}

Mean values within the same station followed by the same capital letter do not differ by PDIFF ( $>0.05)$.. $\mathrm{R}^{2}=$ coefficient of determination of the regression equation. X: $\mathrm{kg} \mathrm{ha}^{-1} \mathrm{~kg} \mathrm{ha}^{-1} \mathrm{year}^{-1} \mathrm{~N}$. SEM: Standard error of the mean. ${ }^{*}(\mathrm{p}<0.05)$ and $* *(\mathrm{p}<0.01)$.

For the dose of $400 \mathrm{~kg} \mathrm{ha}^{-1}$ year $^{-1}$, FAR was higher for coated urea $\left(104 \mathrm{~kg} \mathrm{ha}^{-1}\right.$ day $\left.^{-1}\right)$ than for common urea $\left(70 \mathrm{~kg} \mathrm{ha}^{-1}\right.$ day $\left.^{-1}\right)$ in the fall, which may be related to tiller dynamics, which may have been favored by the slower release of $\mathrm{N}$ to the plant soil system due to lower losses of $\mathrm{N}$ in this season, as described by Martins et al. (2014). 
Silva, A. B. da; et al.

Table 3. Forage accumulation rate of massai grass as a function of urea sources; nitrogen doses; and the summer of 2011/2012 (summer I), autumn, winter and spring of 2012, and summer of 2012/2013 (summer II) seasons.

\begin{tabular}{|c|c|c|c|c|c|c|c|c|}
\hline \multirow{2}{*}{ Seasons } & \multicolumn{5}{|c|}{$\mathrm{N}\left(\mathrm{kg} \mathrm{ha}^{-1} \mathrm{yr}^{-1}\right)$} & \multirow{2}{*}{ SEM } & \multirow{2}{*}{ Equations } & \multirow{2}{*}{$\mathrm{R}^{2}$} \\
\hline & 0 & Ureia & 100 & 200 & 400 & & & \\
\hline \multicolumn{9}{|c|}{ Forage accumulation rate $\left(\mathrm{kg} \mathrm{ha}^{-1} \mathrm{day}^{-1}\right)$} \\
\hline \multirow{2}{*}{ Summer I } & \multirow{2}{*}{$81^{\mathrm{E}}$} & Common & $116^{\mathrm{CD}}$ & $108^{\mathrm{D}}$ & $157^{\mathrm{B}}$ & \multirow{2}{*}{6} & $\hat{\mathrm{Y}}=84.9+0.1741 \mathrm{x}^{* *}$ & 0.88 \\
\hline & & Coated & $112^{\mathrm{CD}}$ & $127^{\mathrm{C}}$ & $210^{\mathrm{A}}$ & & $\hat{\mathrm{Y}}=79.459+0.2834 \mathrm{x}^{* *}$ & 0.97 \\
\hline \multirow{2}{*}{ Autumn } & \multirow{2}{*}{$58^{\mathrm{CD}}$} & Common & $80^{\mathrm{B}}$ & $56^{\mathrm{D}}$ & $70^{\mathrm{BC}}$ & \multirow{2}{*}{5} & $\hat{\mathrm{Y}}=66$ & - \\
\hline & & Coated & $70^{\mathrm{BC}}$ & $67^{\mathrm{BCD}}$ & $104^{\mathrm{A}}$ & & $\hat{\mathrm{Y}}=55.45+0.1114 \mathrm{x}^{* *}$ & 0.88 \\
\hline \multirow{2}{*}{ Winter } & \multirow{2}{*}{$21^{\mathrm{D}}$} & Common & $46^{\mathrm{B}}$ & $33^{\mathrm{C}}$ & $64^{\mathrm{A}}$ & \multirow{2}{*}{3} & $\hat{\mathrm{Y}}=25.05+0.019 \mathrm{x}^{* *}$ & 0.74 \\
\hline & & Coated & $38^{\mathrm{C}}$ & $16^{\mathrm{D}}$ & $70^{\mathrm{A}}$ & & $\hat{Y}=26.89+0.3198 x^{*}$ & 0.59 \\
\hline \multirow{2}{*}{ Spring } & \multirow{2}{*}{$51^{\mathrm{CD}}$} & Common & $46^{\mathrm{CD}}$ & $54^{\mathrm{C}}$ & $65^{\mathrm{B}}$ & \multirow{2}{*}{3} & $\hat{Y}=46.8+0.0415 x^{*}$ & 0.76 \\
\hline & & Coated & $43^{\mathrm{D}}$ & $71^{\mathrm{B}}$ & $87^{\mathrm{A}}$ & & $\hat{\mathrm{Y}}=44.45+0.1053 \mathrm{x}^{* *}$ & 0.82 \\
\hline \multirow{2}{*}{ Summer II } & \multirow{2}{*}{$46^{\mathrm{C}}$} & Common & $122^{\mathrm{A}}$ & $119^{\mathrm{A}}$ & $110^{\mathrm{A}}$ & \multirow{2}{*}{4} & $\hat{\mathrm{Y}}=78.35+0.1205 \mathrm{x}^{*}$ & 0.33 \\
\hline & & Coated & $116^{\mathrm{A}}$ & $109^{\mathrm{A}}$ & $66^{\mathrm{B}}$ & & $\hat{\mathrm{Y}}=62.6+0.2666 \mathrm{x}^{* *}$ & 0.85 \\
\hline
\end{tabular}

Mean values within the same station followed by the same capital letter do not differ by PDIFF $(p>0.05)$.. $\mathrm{R}^{2}=$ coefficient of determination of the regression equation. X: $\mathrm{kg} \mathrm{ha}^{-1} \mathrm{~kg} \mathrm{ha}^{-1}$ year ${ }^{-1} \mathrm{~N}$. SEM: Standard error of the mean. $*(\mathrm{p}<0.05)$ and $* *(\mathrm{p}<0.01)$.

The high rainfall in summer II (Figures 1 and 2) probably favored the greater solubilization of common as compared to coated urea, resulting in more efficient nutrient flow to the fodder and consequently, in greater production $\left(78.35 \mathrm{~kg} \mathrm{ha}^{-1}\right.$ day $^{-1}$ of MS per kg N vs. $62.6 \mathrm{~kg} \mathrm{ha}^{-1}$ day $^{-1}$ of MS per $\mathrm{kg} \mathrm{N}$ ). In addition, it is known that $\mathrm{N}$ fertilizer, especially in the spring and summer seasons, promotes accelerated tillering in grasses owing to the luminosity that results in basilar buds. This in turn is reflected in an increase in the number of tillers, with a high number of leaves per unit area and a high FAR(BARBERO et al., 2009).

\section{Conclusions}

The use of coated urea for $\mathrm{N}$ fertilization linearly increased forage accumulation rate in all seasons of the year and improved the morphological composition of the massai grass forage, mainly in dry seasons.

\section{Acknowledgements}

To the Coordenação de Aperfeiçoamento de Pessoal de Nível Superior (CAPES) for the granting of the scholarship during the Master's Course in the Animal Science Postgraduate Program of UFRRJ.

\section{References}

AZEVEDO, E. B.; PATIÑO, H. O.; SILVEIRA, A. L. F.; LÓPEZ, J.; BRÜNING, G.; KOZLOSKI, G. V. Incorporação de ureia encapsulada em suplementos protéicos fornecidos para novilhos alimentados com feno de baixa qualidade. Ciência Rural, Santa Maria, v. 38, n. 5, p. 1381-1387, 2008.

BARBERO, L. M.; CECATO, U.; LUGÃO, S. M. B.; GOMES, J. A. N.; LIMÃO, V. A.; BASSO, K. C. Produção de forragem e componentes morfológicos em pastagem de coastcross consorciada com amendoim forrageiro. Revista Brasileira de Zootecnia, Viçosa, v. 38, n. 5, p. 788-795, 2009.

CANTARELLA, H. Nitrogênio. In: NOVAIS, R. F.; ALVAREZ, V. H.; BARROS, N. F.; FONTES, R. L.; CANTARUTTI, R. B.; NEVES, J. C. L. (Ed.). Fertilidade do solo. Viçosa, MG: UFV. 2007. p. 375-470.

CARNEVALLI, R. A.; SILVA da, S. C.; BUENO, A. A. O.; UEBELE, M. C.; BUENO, F. O.; HODGSON, J.; SILVA, G. N.; MORAIS, J. P. G. Herbage production and grazing losses in Panicum maximum cv. Mombaça under four grazing managements. Tropical Grasslands, Queensland, v. 40, n. 3, p. 165-176, 2006.

CIVARDI, E. A.; SILVEIRA NETO, A. N. da; RAGAGNIN, V. A.; GODOY, E. R.; BROD, E. Ureia de liberação lenta aplicada superficialmente e ureia comum 
incorporada ao solo no rendimento do milho. Pesquisa Agropecuária Tropical, Goiânia, v. 41, n. 1, p. 52-59, 2011.

COSTA, K. A. D. P.; OLIVEIRA, I. P. D.; FAQUIN, V.; SILVA, G. P.; SEVERIANO, E. D. C. Produção de massa seca e nutrição nitrogenada de cultivares de Brachiaria brizantha (A. Rich) Stapf sob doses de nitrogênio. Ciência e Agrotecnologia, Lavras, v. 33, n. 6, p. 15781585, 2009.

COSTA, N. L., PAUlinO, V. T.; MAGALHÃES, J. A. Produção de forragem, composição química e morfogênese de Panicum maximum cv. Vencedor sob diferentes níveis de adubação nitrogenada. Revista Científica de Produção Animal, Areia, v. 8, n. 1, p. 6672, 2006.

JANK, L.; MARTUSCELLO, J. A.; EUCLIDES, V. B. P.; VALLE, C. B. do; RESENDE, R. M. S. Panicum maximum. In: FONSECA, D. M. da; MARTUSCELLO, J. A. (Ed.). Plantas forrageiras. Viçosa, MG: UFV, 2010. p. 166-196.

LEMPP, B.; SOUZA, F. H. D. de; COSTA, J. C. G.; BONO, J. A. M.; VALÉRIO, J. R.; JANK, L.; MACEDO, M. C. M.; EUCLIDES, V. B. P.; SAVIDAN, Y. H. Capim-massai (Panicum maximum cv. Massai): alternativa para diversificação de pastagens. Campo Grande: Embrapa Gado de Corte, 2001. 5 p. (Embrapa Gado de Corte. Comunicado técnico, 69).

MARTINS, I. S.; CAZETTA, J. O.; FUKUDA, A. J. F. Condições, modos de aplicação e doses de ureia revestida por polímeros na cultura do milho. Pesquisa Agropecuária Tropical, Goiânia, v. 44, n. 3, p. 271-279, 2014.

MARTINS, I. S.; CAZETTA, J. O.; FUKUDA, A. J. F. Condições, modos de aplicação e doses de ureia revestida por polímeros na cultura do milho. Pesquisa Agropecuária Tropical, Goiânia, v. 44, n. 3, p. 271-279, 2014.

MARTUSCELLO, J. A.; SILVA, L. P.; CUNHA, D. N. F. V.; BATISTA, A. C. S.; BRAZ, T. G. S.; FERREIRA, P. S. Adubação nitrogenada em capim-massai: morfogênese e produção. Ciência Animal Brasileira, Goiânia, v. 16, n. 1, p. 1-13, 2015.

MORGAN, K. T.; CUSHMAN, K. E.; SATO, S. Release mechanisms for slow and controlled release fertilizers and strategies for their use in vegetable production. HortTechnology, Alexandria, v. 19, n. 1, p. 101-12, 2009.

PEREIRA, H. S.; LEÃO, F. A.; VERGINASSI, A. Ammonia volatilization of urea in the outof- season corn. Revista Brasileira de Ciência do Solo, Viçosa, v. 33, n. 6, p. 1685-1694, 2009.
PORTO, E. M. V.; VITOR, C. M. T.; ALVES, D. D.; LIMA, M. V. G.; SILVA, M. F. da. Características morfogênicas de cultivares do capim buffel submetidos à adubação nitrogenada. Agropecuária Científica no SemiÁrido, Campina Grande, v. 10, n. 1, p. 14-21, 2014.

PORTZ, A.; RESENDE, A. S.; TEIXEIRA, A. J.; ABBOUD, A. C. S.; MARTINS, C. A. C.; CARVALHO, C. A. B.; LIMA, E.; ZONTA, E.; PEREIRA, J. B. A.; BALIEIRO, F. C.; ALMEIDA, J. C. C.; SOUZA, J. F.; GUERRA, J. G. M.; MACEDO, J. R.; SOUZA, J. N.; FREIRE, L. R.; VASCONCELOS, M. A. S.; LEAL, M. A. A.; FERREIRA, M. B. C.; MANHÃES, M.; GOUVEA, R. F.; BUSQUET, R. N. B.; BHERING, S. B. Recomendações de adubos, corretivos e de manejo da matéria orgânica para as principais culturas de Estado do Rio de Janeiro. In: FREIRE, L. R.; BALIEIRO, F. C.; ANJOS, L. H. C.; PEREIRA, M. G.; LIMA, E.; GUERRA, J. G. M.; FERREIRA, M. B. C.; LEAL, M. A. A.; CAMPOS, D. V. B.; POLIDORO, J. C. Manual de calagem e adubação do Estado do Rio de Janeiro. Seropédica: UFRRJ, 2013. cap. 14, p. 257-414.

PRIMAVESI, A. C.; PRIMAVESI, O.; CORRÊA, L. A.; CANTARElla, H.; SILVA, A. G. da. Absorção de cátions e ânions pelo capim-coastcross adubado com ureia e nitrato de amônio. Pesquisa Agropecuária Brasileira, Brasília, v. 40, n. 3, p. 247-253, 2006.

ROCHA, K. F.; CASSOL, L. C.; PIVA, J. T.; ARRUDA, J. H.; MINATO, E. A.; FAVERSANI, J. C. Épocas de aplicação de nitrogênio na cultura do milho num Latossolo vermelho muito argiloso sob plantio direto. Revista Brasileira de Milho e Sorgo, Sete Lagoas, v. 13, n. 3, p. 273-284, 2014.

ROJAS, C. A. L.; BAYER, C.; FONTOURA, S. M. V.; WEBER, M. A.; VIEIRO, F. Volatilização de amônia da ureia alterada por sistemas de preparo de solo e plantas de cobertura invernais no Centro-Sul do Paraná. Revista Brasileira de Ciência do Solo, Viçosa, v. 36, n. 1, p. 261270, 2012.

SANCHÊS, S. S. C.; GALVÃO, C. M. L.; RODRIGUES, R. C.; SIQUEIRA, J. C.; JESUS, A. P. R.; ARAÚJO, J. S.; SOUSA, T. V. R. Produção de forragem e características morfofisiológicas do capim-mulato cultivado em latossolo do cerrado em função de doses de nitrogênio e potássio. Revista Brasileira de Agropecuária Sustentável, Viçosa, v. 3, n. 1, p. 81-89, 2013.

SANTINI, J. M. K.; BUZETTI, S.; GALINDO, F. S.; DUPAS, E.; COAGUILA, D. N. Técnicas de manejo para recuperação de pastagens degradadas de capimbraquiária (Brachiaria decumbens stapf cv. Basilisk). Boletim de Indústria Animal, Nova Odessa, v. 72, n. 4, p. 331-340, 2015. 
THORNTHWAITE, C. W.; MATHER, J. R. The water balance. Centerton: Drexel Institute of Technology Laboratory of Climatology, 1955. 104 p. (Publications in Climatology, v. VIII, n. 1).
VALDERRAMA, M.; BUZETTI, S.; TEIXEIRA FILHO, M. C. M.; BENETT, C. G. S.; ANDREOTTI, M. Adubação nitrogenada na cultura do milho com ureia revestida por diferentes fontes de polímeros. Semina: Ciências Agrárias, Londrina, v. 35, n. 2, p. 659-670, 2014. 